\title{
The State of the Political Parties in Mongolia: Facts and Conclusions
}

\author{
D. B old-E rdene (M ongolia)
}

7 he major trends of the survey done by the Institute of Philosophy, Sociology and Law, Academy of Sciences,was on the state of political

1 parties and their impact and responsibilities on the social process within the framework of a two-stage project implementation on the "Support in Achieving MDG-9 on human rights and democratic governance in Mongolia".

The process in the state of the political parties has naturally been implemented, and eventually there was no deadlock and interruption in the course of action. Within the survey results, it seems imperfection and insufficient promises in the level of unsatisfactory quality in significance of progression.

\section{State of Political Parties and Research Facts}

Within the research framework, the progression of the state of political parties was conducted by general and special level of emphasizing a point of parties' process in oligarchic and political conducive factors.

From analyzing the research, the practice of oligarchy has been vigorously rising within the political parties. The majority of the researchers and politicians also remarked that Mongolia started 'democracy in oligarchy' in the late 1990s, due to coherence with this progression that political parties converted to an oligarchy grouping. In accordance with the survey results, there are a number of facial characters that have been manipulating to become an oligarchic progression of the political parties development, in owing to poor implementation of legal provisions regulating for financing of political parties and lack of mechanisms to monitor intra-party democracy, and such a chance for political parties neglect the issue and keep producing false financial reports. Albeit, an auditing practice has recently been introduced, there is no open selection for auditing companies and disclosure of audit reports to the public is in unsatisfactory. In addition, cases of unlawful actions related to financing of electoral campaigns and fundraising issues have continuously been observed and may lead to suspicions of corruption practices. 
In accordance with the Law on the Political parties has made fixed provisions in relation to financing of political parties, benefits and assets. There is no imperfection implementation of legal enactment, and lack of mechanisms to monitoring and evaluation process, while the cases of the political parties have been regularly neglected as well. On the behalf, the survey results shown that critical focus for the internal party practices such involved to the oligarchic grouping in the party.

The situation of the party oligarchy grouping is dedicated to the suspicions of corruption practices within the party. In so far, there are various illegal immoralities in related to the financing of political parties and electoral campaign has been concurrence to be building the circumstances of chain reaction of corruption internal party's practices. The major reasons of corruption in the political institution was making complete of a mechanism of financing of political parties and electoral campaign, however, political appointees were being key factors to be corrupted as well. Three of four experts who involved by survey were agreed ${ }^{1}$ that political parties have been corrupted by this current deal with political and electoral system.

By the survey findings, Mongolia has strong power of the political and business grouping in accordance with a personal interest in decision and policymaking process. Accordingly, there seems to be active process in collective grouping of politic-business has been merged with international/foreign grouping of politicbusiness in cooperating with. It's played on hidden corruption circumstance of the political level, and its process being more systematically, and restriction to fighting the corruption in country level.'In the survey piloting, that expansion of corruption in the targeted level has been shown that 58.4 percent of the respondents assumed by the political parties were more corrupted (2009), that regards to assessment of weaken corruption was 4.2 point (1-less corrupted, 5-most corrupted), in accordance with survey of 2010, the corruption was very high for the political parties. In addition, the political parties have assessed by 4.00 point of a predisposition to corruption in political institutions. Wherefrom this condition, the assessment of a predisposition to corruption has increased by 0.08 points for the political parties (2009). ${ }^{3}$ Those above-mentioned points have shown that key abnormalities in the state of political parties have related to being more oligarchies intra-party practices.

\footnotetext{
${ }^{1}$ MDG-9 Project, UNDP Mongolia. Changes in the State of Democratic Governance in Mongolia 2009-2010. Ulaanbaatar, Mongolia. 2010. P 84.

2 Ibid, p 85.

3 MDG-9 Project, UNDP Mongolia. Changes in the State of Democratic Governance in Mongolia 2009-2010. Ulaanbaatar, Mongolia. 2010. P87.
} 


\section{State of political parties and its challenges}

There are many indicators and measurements to indicate the state of political parties. The project research on MDG -9 on human rights and democratic governance has made exacting analysis in the particular of specialties of state of political parties. For instance, the research recommended many critical comments for the state of political parties, and changes of legal provision, responsibilities and social roles of party, and its practical influences, parties electoral and institutional procedures, parties' participation in the democratic institutional stabilities, intraparty democracy practice, morals of the political parties in the policy or decision making process, and financing strength of political parties etc., Accordingly, the survey findings focused on current challenges and sticky issues to carrying out the institutional capabilities of the political parties.

By the observation of survey, the current status of party's legal provision and its regulation is weakness now. It's related to the insufficient changes or bringing together in the relationships between legal provisions and party's activities since 2005. The active tendency have been observing that expansion of political redistribution, in accordance with disintegration and alliance of political parties are raised in the late period of the examination of reform and renovation process dues to gaining to strengthen intra-party practices. Those mentioned process are required to make changes and improvement promulgation to building up parties' legal provisions in strengthening the policies and aspects.

On the behalf, the participation on the political parties is still vigorous power to establishment of the political democratic institutions in Mongolia. Today, public trends and perception of anti-party expansion in the current society, however, there is no chance to developing the political practices that knows about politics and its opportunities of this sphere of trustees. It simply consists of party should be actual party role in the further process.

The trust in political party is one of the major indicators to indicate the state of political parties. The composite indicator calculated on the basis of percentages of respondents that have expressed trust/distrust in political institutions. According to the survey results on trust in institutions ${ }^{4}$ (2010), the public identified political parties as the least trustworthy institutions in Mongolia after Courts, Anticorruption Agency, and General Election Committee etc.

4 MDG-9 Project, UNDP Mongolia. Changes in the State of Democratic Governance in Mongolia 2009-2010. Ulaanbaatar, Mongolia. 2010. p 63 


\section{Chart 1. Dynamics of Trust in Institutions ${ }^{5}$}

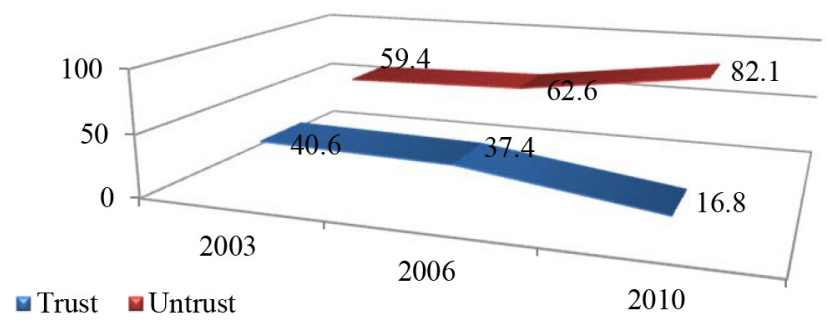

Due to poor implementation ${ }^{6}$ of legal provisions regulating financing of political parties and lack of mechanisms to monitor internal practices, there is a chance for political parties to neglect the issue and keep producing false financial reports. (See on Chart 1)

The survey result shown that weakness of political party system is not being able to strengthen the parliamentary democracy in the parliamentary level in Mongolia. Motivation of the minorities and majorities in the parliament, in regarding to capabilities and actions do not provide for current demands. Accordingly, the majority of SGH members are working as a Cabinet member, that provides for the inappropriate mechanism of monitoring and responsibilities of the Parliament to the Government accountabilities.

Today, there are no legal provisions dealing with issues of compliance by State Great Hural members with their party discipline. The amendment (2010) of the organization and rights and duties of parliamentary parties are determined by the Law of State Great Hural. Party and party coalition factions have duties to ensure "participation of their members in plenary and standing committee sessions, meeting quorums and strict compliance by their members with meeting procedures" (2009). The legislation on the establishment of Ethic code of the SGH members, lack of relationship between parliamentary political parties, suspension of minorities' rights and responsible and party discipline and its legal provisions and other matters pertaining to party structure and activities has not seen any governable possibilities.

One of the major issues in conducting the survey was the state of intra-party democracy and insufficient participation of rank-and -file members. However, reliable data is hardly available because of the absence of any in-depth study into this subject matter of lack of participation of rank-and file members, elaboration of the intra-party democracy etc.,

5 Political Education Academy, Survey conducted within the scope of East Asia Barometer project. 2010.

6 Ibid, p 63. 
There are also major necessities to recommend to building up the transparent and fair procedure to produce an integrated financial status of electoral campaign and political party. The implementation of legal provisions, however, is not being compiled with. The lack of mechanism to monitoring and charge in financing of political parties, as well that is basis on the conflict of step out of law enforcement and lawlessness and lost in party discipline.

\section{State of political parties and its bottlenecks}

The survey recommends that the following aspects are required inconsidering the state of political parties to enhance the acceleration of sufficieny:

- Making amendments/changes in the Law on Political parties based on political transformation, in accordance with the state and tendency of political parties, that regards to bringto perfection of legal provisions of the political parties;

- To fundamentally innovation of party reform on the current platform, not for present background of party;

- To hesitate the principles of steely membership and reversing organization of party to be compact and carriage able;

- To implement the courageous oriented steps to promoting the trust of voters in regards to carried out the sufficient and business initiative political actions for improving the scientific/academic trends to building up the party election program and its opportunities of policy and decision making process;

- To develop the legal provisions to conceptualized arrangements on minority status, orientation and morals in the parliamentary level, and emphasizing the mechanisms to discipline and responsibilities of the political parties in the parliamentary level;

- In accordance with improvement for monitoring and accountabilities of the Parliament to the Government actions being appropriated controlling morals of SGH members work as a Cabinet member;

- To build up lack of mechanism in political, ethics, and monitoring or responsibilities from voters to the SGH members, and intensifying their impacts;

- To develop the intra-party democracy and insufficient participation of rank-and -file membersand party promoters;

- To systemize the transparent and fair of financing of political parties, and transferring to state budget financing of the political parties which are elected by parliamentary status. 